\section{Do the rubber plantations in tropical China act as large carbon sinks?}

\author{
Qing-Hai Song ${ }^{(1-2)}$, Zheng-Hong Tan ${ }^{(1-2)}$, Yi-Ping Zhang ${ }^{(1-2)}$, Li-Qing Sha ${ }^{(1)}$, \\ Xiao-Bao Deng ${ }^{(1)}$, Yun Deng ${ }^{(1)}$, Wen-Jun Zhou ${ }^{(1-2)}$, Jun-Fu Zhao ${ }^{(1-2)}$, \\ Jun-Bin Zhao ${ }^{(1-2)}$, Xiang Zhang ${ }^{(1-5)}$, Wei Zhao ${ }^{(1-5)}$, Gui-Rui Yu ${ }^{(3)}$, Xiao-Min \\ Sun ${ }^{(3)}$, Nai-Shen Liang ${ }^{(4)}$, Lian-Yan Yang ${ }^{(1-2)}$ \\ The regrowth of tropical secondary forests and plantations can not offset the \\ carbon release caused by tropical deforestation, consequently determining net \\ carbon losses on tropical lands. However, large uncertainties remain in relation \\ to this assumption. Here, we used a biometric method to estimate the net dry \\ matter production and net ecosystem production in a rubber forest, the most \\ widespread plantation type in tropical Southeast Asia. According to biometric \\ estimates made during the study, the ecosystem was a carbon sink $\left(790 \mathrm{gC} \mathrm{m}^{-2}\right.$ \\ $\left.\mathrm{yr}^{-1}\right)$. Net ecosystem carbon fluxes were measured by the eddy covariance \\ method. The carbon budget estimated using the FluxNet procedure $\left(904 \mathrm{gC} \mathrm{m}^{-2}\right.$ \\ $\mathrm{yr}^{-1}$ ) was closer to the biometric estimates in comparison to a method based on \\ data measured during neutral atmospheric conditions. Overall, when conside- \\ ring the whole life cycle, including deforestation of the prior-existing tropical \\ forest, the hypothesis of plantations serving as large carbon sinks is not sup- \\ ported by our study.
}

Keywords: Carbon Sink, Eddy Flux, Biometric Method, Neutral Atmospheric Condition

\section{Introduction}

The largest errors in assessing the terrestrial carbon balance are believed to stem from uncertain rates of tropical deforestation or rainforest conversion (Houghton \& Goodale 2004, Houghton 2005). The conversion of tropical rainforest into plantations affects vegetation and soils and thus changes the amount of stored and fixed carbon in an ecosystem. The carbon released to the atmosphere by the destruction of tropical rainforests in Indonesia during 1981-1990 was $9.3 \times 10^{14} \mathrm{gC}$ (Hashimotio et al. 2000), while the net release of carbon associated with land use change in sub-Saharan Africa over the period 2000-2005 was estimated to be

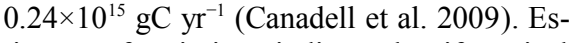
timates of emissions indicate that if tropical grasslands are replaced by oil palm plantations, then carbon fixation in plantation biomass and soil organic matter results in the net removal of about $1.35 \times 10^{8} \mathrm{~g} \mathrm{CO}_{2} \mathrm{ha}^{-1}$ from the atmosphere during the first 25-year cycle of oil palm growth (Germer \& Sauerborn 2008). Stimulated by the high price of rubber (Hevea brasiliensis), rubber plantations have been replacing primary tropical years in China. In Xishuangbanna, Yunnan Province, plantations cover an area of $2.87 \times$ $10^{5}$ ha (statistical data are from 2011), and have spread to most areas except for protecrainforests with dramatic speed in recent

(1) Key Laboratory of Tropical Forest Ecology, Xishuangbanna Tropical Botanical Garden, Chinese Academy of Sciences, RC-666303 Menglun (China); (2) Global Change Ecology Group, Xishuangbanna Tropical Botanical Garden, Chinese Academy of Sciences, RC-650223 Kunming (China); (3) Institute of Geographic Sciences and Natural Resources Research, Chinese Academy of Sciences, RC-100101 Beijing (China); (4) Global Carbon Cycle Research Section, Center for Global Environmental Research, National Institute for Environmental Studies, J-305-8506 Tsukuba (Japan); (5) University of the Chinese Academy of Sciences, RC-100094 Beijing (China)

@) Yi-Ping Zhang (yipingzh@xtbg.ac.cn)

Received: Nov 15, 2012 - Accepted: Aug 30, 2013

Citation: Song Q-H, Tan Z-H, Zhang Y-P, Sha L-Q, Deng X-B, Deng Y, Zhou W-J, Zhao J-F, Zhao J-B, Zhang X, Zhao W, Yu G-R, Sun X-M, Liang N-S, Yang L-Y, 2014. Do the rubber plantations in tropical China act as large carbon sinks? iForest 7: 42-47 [online 2013-10-21] URL: http://www.sisef.it/iforest/contents/?id=ifor0891-007

Communicated by: Giorgio Matteucci ted nature reserves. This growth exceeded the expectations of the Chinese government, which encouraged and invested heavily in the planting of rubber trees to secure China's social and economic development at the beginning of the 1950s. Rubber is not just an economic crop, but represents an important environmental issue of concern to the public, government, and the scientific community. Environmentalists tend to believe that planting rubber will induce more carbon release, lead to severe drought, and harm the environment, whereas the government states that rubber plantations are forests just like any other forest and will not cause any environmental harm.

Currently, the micrometeorological-based eddy covariance method is widely used for the investigation of carbon balance in a variety of ecosystems (Aubinet et al. 2000, Baldocchi 2008, Kato \& Tan 2008). The strength of this method lies in its efficacy in providing high temporal resolution flux data with a spatial representativeness of hundreds of hectares under slight to no disturbance when compared with traditional biometric methods (Knohl et al. 2009). However, night time eddy flux data, commonly used to estimate ecosystem respiration and a necessary part of the annual carbon balance assessment, has been criticized for its low reliability (Goulden et al. 1996, Miller et al. 2004, Papale et al. 2006, Moffat et al. 2007). To address this problem, the friction velocity $\left(u^{*}\right)$ correction method is used as a standard step in annual carbon budget assessments, from site-specific analysis to FluxNet community synthesis (Goulden et al. 1996, Valentini et al. 2000, Reichstein et al. 2005). Nevertheless, in some cases $u^{*}$ has not been a proper indicator of turbulence intensity (Acevedo et al. 2009), while in other cases, it was not possible to estimate a $u^{*}$ threshold for some sites (Takanashi et al. 2005, Tan et al. 2011) or more than half of the nighttime data were removed after $u^{*}$ filtering (Saleska et al. 2003, Tan et al. 2010). Extrapolating these sometimes limited data to annual budgets will therefore cause greater uncertainty, and filling data gaps provides another substantial challenge (Falge et al. 2001, Moffat et al. 2007).

An alternative to the above approach is the use an inventory-based biometric method, which has been used to estimate forest Net Ecosystem Productivity (NEP), although there are limits to the estimation of soil $\mathrm{C}$ sequestration. In the tropics, eddy covariance-based carbon budgets have been reported to be generally higher than biometric estimates both before and after $u^{*}$ filtering (Malhi et al. 1998, Saleska et al. 2003, Miller et al. 2004, Hutyra et al. 2007, Tan et al. 2010, Wolf et al. 2011). As large uncertainties are associated with both methods, the question 
is which one should be adopted when assessing specific forest carbon budgets (Saleska et al. 2003). In tropical rain forests, the high and uneven canopy, the high biodiversity, and the strong heterogeneity of the environment introduce extra uncertainties to measurements and data interpretation. For example, approximately 300 allometric measures per hectare were needed to fulfill the standard for species-specific allometric equations required for biomass estimations (Cao et al. 2006). This was unfeasible in field conditions, in that, e.g., exact breast-girth data were not available due to the presence of buttress roots (Clark et al. 2001).

In the Xishuangbanna tropical rainforest, both long-term catchment water observations and direct eddy covariance estimates indicate that more water underwent evapotranspiration in the rubber plantations than in the rainforest (Tan et al. 2012). However, little knowledge or observational data on carbon fluxes has been available so far.

In this investigation, we assessed the carbon budget of a 33-year-old rubber plantation in tropical China. Specifically, this study was designed to determine: (1) if adult tropical rubber plantations are carbon sinks or sources; (2) whether eddy covariance and biometric estimates converge in a monoculture forest; and (3) if rubber plantations are a potential carbon sink when compared to primary tropical rainforest.

\section{Methods}

\section{Site description}

The study site is located in the experimental area of the Xishuangbanna Tropical Botanical Garden $\left(21^{\circ} 55^{\prime} 30^{\prime \prime} \mathrm{N}, 101^{\circ} 15^{\prime}\right.$ '59" $\mathrm{E}$; size $\sim 20$ ha; elevation $570 \mathrm{~m}$ a.s.1.), Xishuangbanna, Yunnan Province, south-western China. In recent years, tropical rainforests have been largely replaced across the whole region by rubber plantations for economic reasons. The Xishuangbanna experimental area was established by the Chinese Academy of Sciences to study the impact of widespread rubber plantations on the local environment. The study site is included in a larger area, all planted with rubber trees.

The climate in this area is strongly seasonal with two air masses alternating over the year (Zhang 1966). Between May and October, the tropical southern monsoon from the Indian Ocean delivers most of the region's annual rainfall, whereas the dry and cold air of the southern edges of the subtropical jet stream dominates the climate between November and April (Tan et al. 2010). The mean annual rainfall over the past 50 years was $1492 \mathrm{~mm}$, and approximately $87 \%$ of this rainfall occurred during the wet half of the year (the rainy season). The mean annual temperature is $21.7^{\circ} \mathrm{C}$, with monthly mean values ranging from 15.9 to $25.7{ }^{\circ} \mathrm{C}$ (Tan et al. 2010). The general topography of the area is essentially hilly terrain.

The 33-year-old rubber plantation studied has a mean canopy height of approximately $22 \mathrm{~m}$. Trees were planted $2 \mathrm{~m}$ apart in rows with mixed spacing between the rows, from narrow $(4 \mathrm{~m})$ to wide $(12 \mathrm{~m})$, The main rubber-tapping period is from May to November. Fertilization is performed in April and July of each year, and understory weeds and seedlings are excluded using herbicides or by hand weeding.

\section{Biometric-based NEP estimations}

Assessment of the net ecosystem production was carried out by the forest department using the most commonly employed biometric method (Kira \& Shidei 1967, Lieth \& Whittaker 1975 - eqn. 1):

$$
N E P_{c}=N P P-R_{h}=\Delta B+L_{p}-R_{h}
$$

where $N E P_{\mathrm{c}}$ is commonly defined as the net ecosystem production, NPP is the net primary production, $R_{\mathrm{h}}$ is the soil heterotrophic respiration, $\Delta B$ is the biomass increment, and $L_{\mathrm{p}}$ is aboveground and belowground litterfall production.

For rubber plantations, rubber tapping (as it relates to carbon loss) should be included in the NEP estimation. Thus, eqn. 1 was modified to (eqn. 2):

$$
N E P_{r}=N E P_{c}+P_{r t}
$$

where $N E P_{\mathrm{r}}$ is the adjusted $N E P$ for the rubber plantation and $P_{\mathrm{rt}}$ is the carbon lost from rubber tapping.

A method based on tree growth theory was proposed for estimating the biomass increment. Using the assumption that the biomass accumulation of a monoculture stand will be similar to that of individual tree growth, the logistic equation was used to fit the stand age vs. stand biomass curve. For a normal year, the biomass increment was then calculated as follows (eqn. 3):

$$
\Delta B=C_{t+1}-C_{t}
$$

where $t$ is the year since planting, $t$ is a positive integer starting from 1 , and $C_{\mathrm{t}}$ is the carbon density in year $t$ as calculated from the specific logistic equation. Rubber trees in plantations usually live no longer than 60 years, and trees 40 years or older exhibit low rubber production and are generally felled by farmers.

In our study area, we selected a stand where the age series ranged from 5 to 47 years. By using the investigation data of 30 rubber trees with different ages in the 10 stands (3 trees per stand) and diameter at breast height, a regression model of the biomass relating with DBH (diameter at breast height, $1.3 \mathrm{~m}$ ) was established and applied to estimate the biomass of 30 rubber plantations with different stand ages (Tang et al. 2009). Biomass was then converted into carbon density using a factor of 0.5 (Tan et al. 2010). Litterfall production was estimated using the litter capture method. Twenty 0.25 $\mathrm{m}^{2}$ litter traps were placed randomly within 1 hectare of the area covered by the eddy flux footprint. All litter collections were sorted into leaves, small branches, flowers, fruits, epiphytic materials and "mixed matter," and then dried to constant weight at $80^{\circ} \mathrm{C}$.

We selected 4 plots $(10 \times 15 \mathrm{~m})$ in the rubber plantation and 3 sub-plots $(4 \times 5 \mathrm{~m})$ in each plot, which were set as control (CK) and root trenching (NR). In the NR plots, we used a PVC pipe $(\varnothing 630 \mathrm{~mm}, \mathrm{H} 500 \mathrm{~mm})$ to carry out root trenching (PVC pipes can prevent new root regrowth). In the center of each sub-plot one PVC connector was inserted 3 $\mathrm{cm}$ underground, mating a PVC pipe $(\varnothing 200$ $\mathrm{mm}, \mathrm{H} 200 \mathrm{~mm}$ ), creating a respiration box for measuring soil respiration. Soil respiration was measured using a static chamber combined with an infrared gas analyzer (Li820, Li-Cor Inc., Lincoln, NE, USA). Sampling was performed every morning between 09:00 and 11:00 local time from March 2008 to February 2009 ( $\mathrm{Lu}$ et al. 2009).

\section{Eddy covariance-based NEE estimations}

An open-path eddy covariance system consisting of a three-dimensional sonic anemometer (CSAT3, Campbell Scientific Inc., Logan, UT, USA) and an open-path infrared gas analyzer (Li-7500, Li-Cor Inc., Lincoln, NE, USA) were mounted at a height of 38.0 $\mathrm{m}$ on a 55-meter iron meteorological observation tower (Fig. S1). Seven levels of instruments (at 2.2, 8.7, 16.8, 21.3, 28.9, 37.8, and $56.6 \mathrm{~m}$ ) were mounted on the tower to obtain profiles of wind speed (A100R, Vector Instruments, Denbighshire, UK), air temperature, and relative humidity (HMP45C, Vaisala, Helsinki, Finland). Instruments for measuring wind direction (W200P, Vector Instruments, Denbighshire, UK) and rainfall (Rain Gauge 52203, R. M. Young Co., Traverse City, MI, USA) were installed at the top of the tower. Net radiation was calculated from the downward and upward, shortand long-wave radiation (CNR-1/CM11, Kipp \& Zonen, Delft, the Netherlands) at a height of $28.6 \mathrm{~m}$. Photosynthetically-active radiation was measured using linear sensors (LQS70-10, APOGEE, USA) at heights of 1.9 and $28.6 \mathrm{~m}$. Soil moisture and temperature profiles were also monitored (CS616-L, Campbell, USA and 105/107 L, Campbell, USA, respectively). Two soil heat flux plates (HFP01, Hukseflux, the Netherlands), installed in south- and north-facing orientations, were used to measure the average soil heat flux. Eddy flux and meteorological data were separately collected using a CR5000 (Camp- 
bell Inc., USA) at a frequency of $10 \mathrm{~Hz}$ and a CR1000 (Campbell Inc., USA) every 30 min.

The net ecosystem $\mathrm{CO}_{2}$ exchange (NEE) was calculated as follows (eqn. 4):

$$
N E E=F_{c}+F_{s}=\overline{\omega^{\prime} c^{\prime}}+\frac{\Delta c}{\Delta t} \cdot z_{r}
$$

where $F_{\mathrm{c}}$ is the eddy flux, $F_{\mathrm{s}}$ is the storage flux, $\omega$ is the vertical wind velocity, $c$ is the density of $\mathrm{CO}_{2}$, the primes denote deviations from the mean and the over-bar indicates a time average, $\Delta c$ is the variation in $\mathrm{CO}_{2}$ concentration, $\Delta t$ is the time interval, and $z_{\mathrm{r}}$ is the reference height $(38.0 \mathrm{~m})$. By convention, negative NEE values indicate $\mathrm{CO}_{2}$ flux from the atmosphere into the forest. Thus, NEE is equal to NEP, but with an opposite sign.

The software used to perform the eddy flux data processing is recommended by FluxNet and maintained online by the Max Planck Institute (http://www.bgc-jena.mpg.de/ MDIwork/eddyproc/index.php). The used software implements the Reichstein $u^{*}$ filtering and the flux-partitioning method (Reichstein et al. 2005), as well as the Lasslop flux-partitioning method (Lasslop et al. 2010). Before data processing, all commonly used steps, such as coordinate rotation (Tanner \& Thurtell 1969), WPL correction (Webb et al. 1980), storage flux correction, and hard spike exclusion, were performed.

Micrometeorological theories and hypotheses are generally more accurate under neutral atmospheric conditions. Based on this consideration, we also used a method called "neutral atmospheric condition based eddy flux estimation" to process our carbon budget dataset. In this procedure, we selected the neutral atmospheric condition data $(-1<\xi<1)$ which accounted for about $80 \%$ of all data, and filled the gap during non-neutral atmospheric conditions with environmental response curves derived from neutral atmospheric conditions (Tan et al. 2011). The atmospheric stability index $(\xi)$ used in our method was obtained as follows (eqn. 5):

$$
\xi=\frac{z}{L}=\frac{\kappa \cdot g \cdot \theta_{*} \cdot\left(z_{r}-d\right)}{\theta \cdot u_{*}^{2}}=\frac{\kappa \cdot g \cdot \overline{w^{\prime} \theta^{\prime}} \cdot\left(z_{r}-d\right)}{\theta \cdot u_{*}^{3}}
$$

where $L$ is the Monin-Obukhov length, $\kappa$ is the Karman constant $(0.41), g$ is gravitational acceleration $\left(9.8 \mathrm{~m} \mathrm{~s}^{-2}\right), \theta_{*}$ is the temperature scale, $z_{\mathrm{r}}$ is the measurement height (m), $\theta$ is the potential temperature, $u_{*}$ is the friction velocity, $w$ is the vertical wind velocity, and $d$ is the zero-plane displacement height $(\mathrm{m})$, which is specific for tall vegetation and was derived from the wind profile data.

Additional data quality assessments, such as ecosystem energy closure (Fig. S2), spectrum analysis (Fig. S3), flux environmental response (Fig. S4), and cumulative fre-

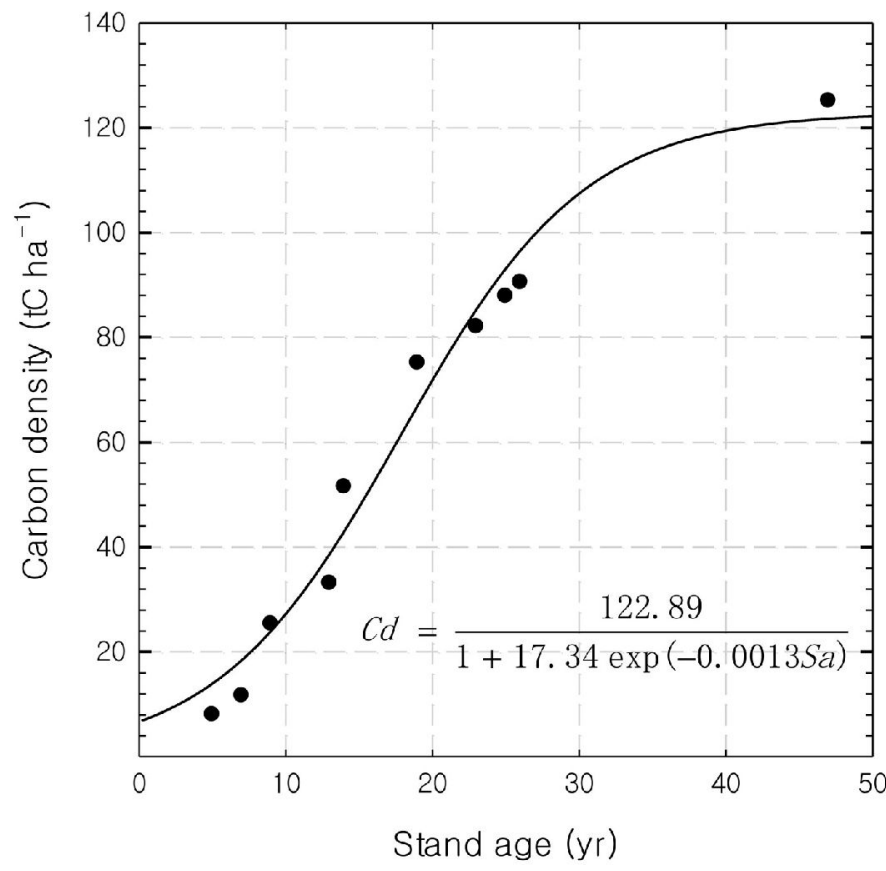

Fig. 1 - The relationship between stand age and carbon density for the rubber plantation studied.

quency distribution of wind speed (Fig. S5) were also performed.

\section{Results}

Logistic equations can be used to describe the relationship between stand age and carbon density as expected (Fig. 1). The predicted maximum carbon density of the rubber stands was $122.89 \mathrm{tC} \mathrm{ha}^{-1}$ at the age of 49 years. The largest carbon accumulation rate $\left(4.9 \mathrm{tC} \mathrm{ha}^{-1} \mathrm{yr}^{-1}\right)$ occurred at 17 years. The biomass increment from 32 to 33 years as calculated from the equation was $1.37 \mathrm{tC}$ $\mathrm{ha}^{-1} \mathrm{yr}^{-1}$ (which is equal to $137 \mathrm{gC} \mathrm{m}^{-2} \mathrm{yr}^{-1}$ ).

Rubber tree is an evergreen species in its native habitat, but in our study area trees become deciduous and shed their leaves after the coldest month (January). Aboveground litterfall production peaked in February (Fig. 2). The second aboveground litterfall peak in September was connected with fruit production. The annual aboveground litterfall production observed at the site was approxi-

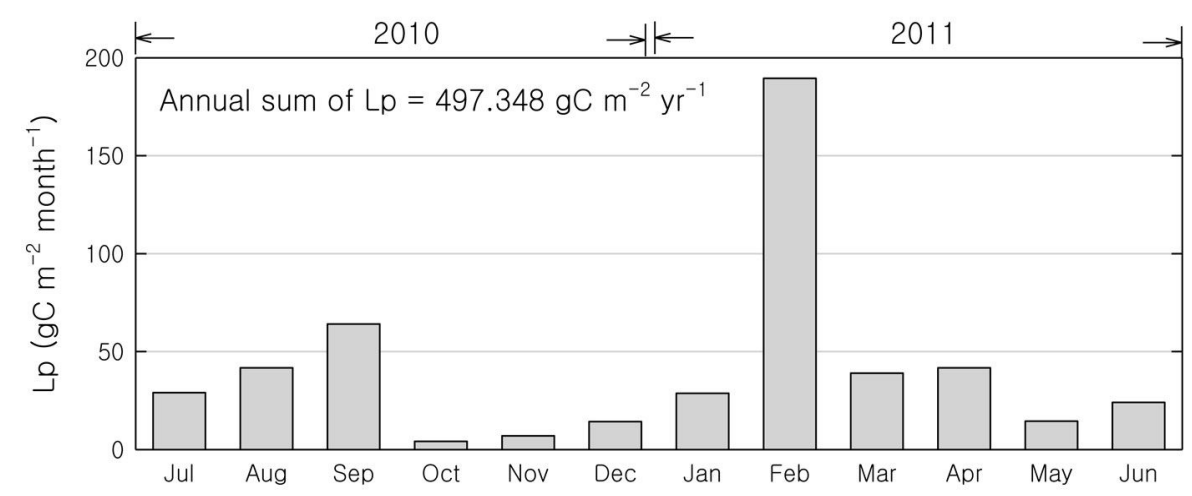

Fig. 2 - The monthly variations of aboveground litterfall production $\left(L_{\mathrm{p}}\right)$ in the rubber plantation from July 2010 to June 2011. mately $497 \mathrm{gC} \mathrm{m}^{-2}$. In this study, we did not measure the belowground litterfall production. If we conservatively assume that belowground litter input at this site is similar to aboveground litterfall (Davidson et al. 2002), the total litterfall production was about $1000 \mathrm{gC} \mathrm{m}^{-2}$.

Soil respiration was higher during the rainy season than during the dry season, while the heterotrophic to total respiration ratio was higher during the dry season than during the rainy season (Fig. 3). Highest total and heterotrophic respiration were observed in September $\left(2.5 \mu \mathrm{mol} \mathrm{m} \mathrm{m}^{-2} \mathrm{~s}^{-1}\right)$ and July $(1.9 \mu \mathrm{mol}$ $\left.\mathrm{m}^{-2} \mathrm{~s}^{-1}\right)$. The annual heterotrophic respiration was about $445 \mathrm{gC} \mathrm{m}^{-2}$. We compared our soil respiration data with previously reported estimates at the same site using the soda lime ding no significant differences (2.02 vs. 2.06 $\mu \mathrm{mol} \mathrm{m} \mathrm{m}^{-2} \mathrm{~s}^{-1}$, respectively). Spatial heterogeneity in soil respiration was small at this site. absorption method (Fang \& Sha 2006), fin- 


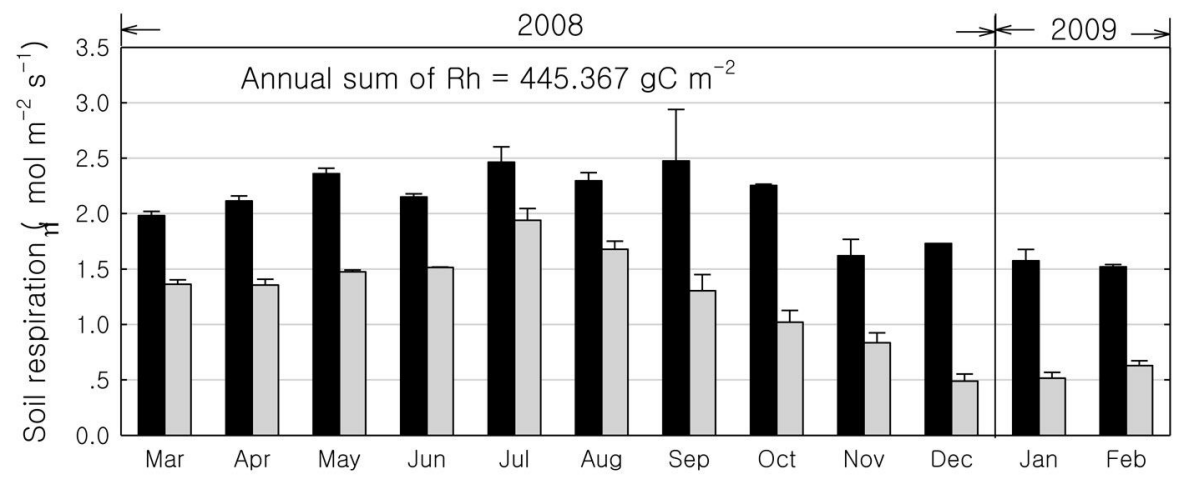

Fig. 3 - The monthly variations of soil respiration in the rubber plantation from March 2008 to February 2009. (Black columns): total soil respiration; (grey columns): heterogeneity respiration).

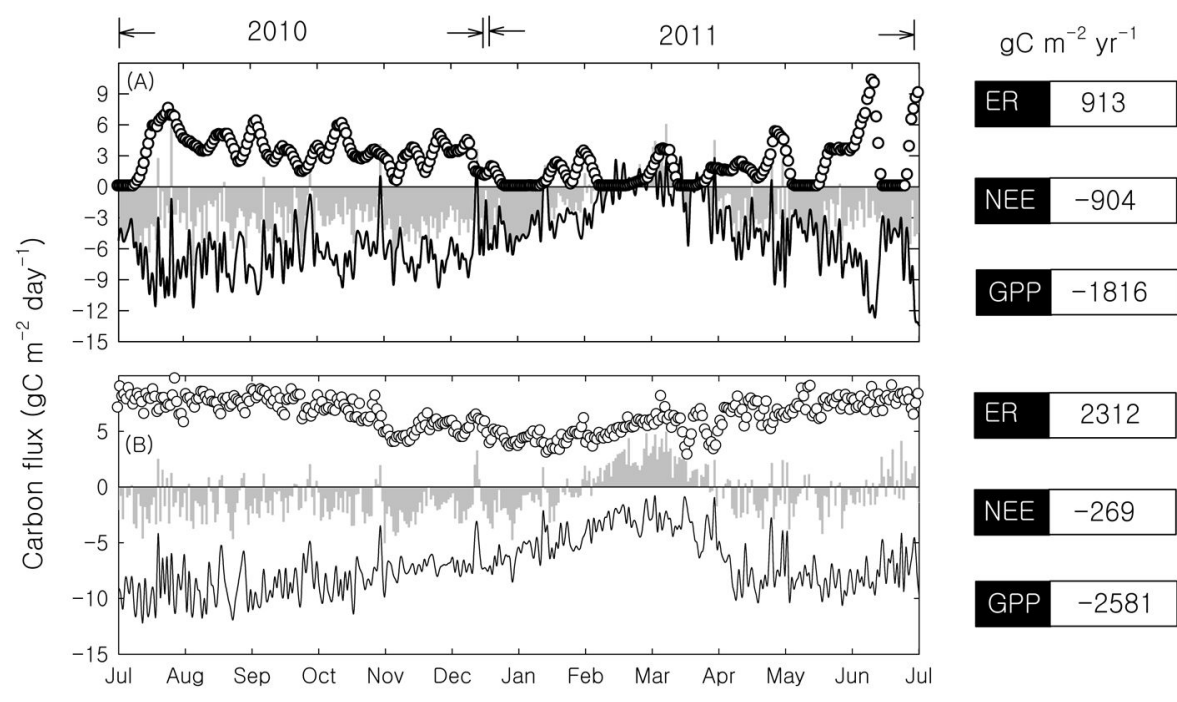

Fig. 4 - The carbon flux of the rubber plantation by different data processing procedures. (A): FluxNet procedure method; (B): Neutral atmospheric condition method; (hollow circles): ecosystem respiration (ER); (grey columns): $N E E$; (black lines): GPP.

Based on the presented data and according to eqn. $1, N E P_{\mathrm{c}}$ was estimated to be $692 \mathrm{gC}$ $\mathrm{m}^{-2} \mathrm{yr}^{-1}$. The annual dry rubber production in our study area is $112 \mathrm{gC} \mathrm{m}^{-2}$. The carbon content of dry rubber was measured at $88 \%$ (Jiang \& Wang 2002). Thus, $P_{\mathrm{rt}}$ and $N E P_{\mathrm{c}}$ were estimated to be $98 \mathrm{tC} \mathrm{ha}^{-1} \mathrm{yr}^{-1}$ and 790 $\mathrm{tC} \mathrm{ha}^{-1} \mathrm{yr}^{-1}$, respectively. Thus the biometric estimation provided a $N E P$ close to the value derived by the FluxNet procedure method (904 gC m $\mathrm{gr}^{-1}$ - Fig. 4A).

To avoid the effects of calm nights and strong winds, the neutral atmospheric condition method has been used as an alternative approach to studying an ecosystem's carbon balance (Tan et al. 2011). The neutral atmospheric condition method provided a moderate $N E E\left(-269 \mathrm{gC} \mathrm{m}^{-2} \mathrm{yr}^{-1}\right)$ and large $G P P$ $\left(-2.581 \mathrm{gC} \mathrm{m}^{-2} \mathrm{yr}^{-1}\right.$ - Fig. 4B). Thus the application of the neutral atmospheric condition method provided estimates of $N E E$ fair- ly different from those obtained using both biometric- and FluxNet-based procedures. However, the seasonal pattern derived from the neutral atmospheric condition method makes it interesting for such analyses, if further refined.

\section{Discussion}

According to traditional biometric methods, the 33-year-old rubber plantation in our study is a carbon sink $\left(790 \mathrm{gC} \mathrm{m}^{-2} \mathrm{yr}^{-1}\right)$. This value is larger than that obtained from a young Acacia crassicarpa plantation in south China (330 $\mathrm{gC} \mathrm{m}^{-2} \mathrm{yr}^{-1}$ - Chen et al. 2011), and significantly lower than estimates from a young Eucalyptus urophylla stand (1.960 $\mathrm{gC} \mathrm{m}^{-2} \mathrm{yr}^{-1}$ - Chen et al. 2011). The largest biomass increment (490 $\left.\mathrm{gC} \mathrm{m}^{-2} \mathrm{yr}^{-1}\right)$ occurred at 17 years. Assuming that the litterfall input and soil heterotrophic respiration are in a balanced state (Tan et al. 2010), the peak $N E P_{\mathrm{c}}$ of the rubber plantation is $1045 \mathrm{gC} \mathrm{m}^{-2} \mathrm{yr}^{-1}$, which is quite a large carbon sink, as suggested by previous studies (Chen et al. 2011). The biometric method cannot provide high temporal resolution for net carbon balances without disturbances. However, it can provide reliable annual carbon balance estimates, which can be used as a baseline value for more accurate studies based on eddy flux data processing.

The closest site to the rubber plantation at which comparable carbon flux measurements have been made is a primary tropical rainforest (approximately $10 \mathrm{~km}$ distant). The carbon sink strength ( $\left.790 \mathrm{~g} \mathrm{C} \mathrm{m}^{-2} \mathrm{yr}^{-1}\right)$ of the rubber plantation is higher than that of the tropical rainforest $\left(359 \mathrm{gC} \mathrm{m}^{-2} \mathrm{yr}^{-1}\right.$, based on the biometry method - Tan et al. 2010). Fertilizer input in the rubber plantation can increase the biomass accumulation. Over time, this may cause a gradual increase in the strength as carbon sink of the plantation. However, such an increase might potentially be totally or partially offset if soil respiration increased.

Belowground litter input plays an important role in the production estimation. According to previous studies, belowground litter production is reported to be even twice as large as aboveground litterfall (Davidson et al. 2002). The actual $N E P$ at our site may be much higher $\left(1200 \mathrm{~g} \mathrm{C} \mathrm{m}^{-2} \mathrm{yr}^{-1}\right)$. Eddy flux measurements are dependent on several QA/ QC steps, such as $u^{*}$ filtering and gap filling (Malhi et al. 1998, Saleska et al. 2003). Gap filling is often a challenge when eddy covariance datasets are complex (Saleska et al. 2003), resulting in NEP estimation based on different methods that are sometimes not very close. In this study, we used data collected in neutral atmospheric conditions (which we call the neutral atmospheric condition method) to fill the data measured under non-neutral atmospheric conditions. The resulting NEE $\left(-2.69 \mathrm{tC} \mathrm{ha}^{-1} \mathrm{yr}^{-1}\right)$ produced by the neutral atmospheric condition method is not close to the value obtained by biometric estimation (-7.90 $\left.\mathrm{tC} \mathrm{ha}^{-1} \mathrm{yr}^{-1}\right)$ and by the FluxNet procedure $\left(-9.04 \mathrm{tC}^{-1} \mathrm{ha}^{-1} \mathrm{yr}^{-1}\right)$. This is possibly related to the fact that the range selected for the neutrality of atmospheric conditions is not within the commonly recognized range. Instead, we do not consider the complete life cycle of the rubber plantation, starting with the deforestation of the previous tropical forest. Most of these data represent the biomass at a certain age without stating actual and maximum trunk height. Available data do contain inherent uncertainties associated with the lack of the complete life cycle. However, the seasonal patterns obtained using the neutral atmospheric condition method provide support for a further refinement of the method, with the aim of its possible future use to derive annual budgets, that should be primarily 
based on the evaluation of the impact of the different range of the stability index chosen for the application of the method.

\section{Conclusions}

According to the biometric estimates and the eddy-flux $N E E$ derived with FluxNet procedure, the ecosystem studied was an important carbon sink, while the neutral atmospheric condition method provided a significantly lower $N E E$. If we consider the complete life cycle of the rubber plantation, starting from deforestation of the previous tropical forest, the hypothesis of plantations serving as large carbon sinks is not supported by our study. Here, only the carbon balance was examined for large-scale planting of rubber trees. Other important environmental issues, such as biodiversity loss, soil erosion, should be examined in the future.

\section{Acknowledgments}

We thank Xiao-Long Bai, Xue-Hai Fei, Jin-Xiang Xiong and Hong-Li Ji for their assistance in the field. This work was supported by Xishuangbanna Station for Tropical Rain Forest Ecosystem Studies (XSTRE), and by the National Science Foundation of China (41001063, 41271056, 41071071, 31200347), the Development Program in Basic Science of China (2010CB833501), the "Strategic Priority Research Program" of the Chinese Academy of Sciences (Grant no. XDA05070303) and the Chinese Academy of Sciences 135program (XTBG-T03).

\section{References}

Acevedo OC, Moraes OLL, Degrazia GA, Fitzjarrald DR, Manzi AO, Campos JG (2009). Is friction velocity the most appropriate scale for correcting nocturnal carbon dioxide fluxes? Agricultural and Forest Meteorology 149: 1-10. - doi: 10.1016/j.agrformet.2008.06.014

Aubinet M, Grelle A, Ibrom A, Rannik U, Moncrieff J, Foken T, Kowalski AS, Martin P, Berbigier P. Bernhofer C, Clement R, Elbers J, Granier A, Grunwald T, Morgenstern K, Pilegaard K, Rebmann C, Snijders W, Valentini R, Vesala $\mathrm{T}$ (2000). Estimates of the annual net carbon and water exchange of forests: the EUROFLUX methodology. Advances in Ecological Research 30:113-175. - doi: 10.1016/S0065-2504(08)600 18-5

Baldocchi DD (2008). "Breathing" of the terrestrial biosphere: lessons learned from a global network of carbon dioxide flux measurement systems. Australian Journal of Botany 56:1-26. doi: 10.1071/BT07151

Canadell JG, Raupach MR, Houghton RA (2009). Anthropogenic $\mathrm{CO}_{2}$ emissions in Africa. Biogeosciences 6: 463-468. - doi: 10.5194/bg-6-4632009

Cao M, Zhou X, Warren M, Zhu H (2006). Tropical Forests of Xishuangbanna, China. Biotropica 38: 306-309. - doi: 10.1890/06-1336.1

Chen DM, Zhang CL, Wu JP, Zhou LX, Lin YB,
Fu SL (2011). Subtropical plantations are large carbon sinks: evidence from two monoculture plantations in South China. Agricultural and Forest Meteorology 151: 1214-1225. - doi: 10.1016/j.agrformet.2011.04.011

Clark DA, Brown S, Kicklighter DW, Chambers JQ, Thomlinson JR, Jian N, Holland EA (2001). Net primary production in tropical forests: an evaluation and synthesis of existing field data. Ecological Applications 11: 371-384. - doi: 10.1890/1051-0761(2001)011[0371:NPPITF]2.0 .CO;2

Davidson EA, Savagea K, Bolstad P, Clark DA, Curtis PS, Ellsworth DS, Hanson PJ, Law BE, Luo Y, Pregitzer KS, Randolph JC, Zak D (2002). Belowground carbon allocation in forests estimated from litterfall and IRGA-based soil respiration measurements. Agricultural and Forest Meterology 113: 39-51. - doi: 10.1016/ S0168-1923(02)00101-6

Falge E, Baldocchi DD, Olson RJ, Anthoni P, Aubinet M, Bemhofer C, Burba G, Ceulemans R, Clement RJ, Dolman AJ, Granier A, Gross P, Grünwald T, Hollinger DY, Jensen NO, Katul G, Keronen P, Kowalski A, Lai CT, Law BE, Meyers T, Moncrieff J, Moores E, Munger JW, Pilegaard K, Rannik Ü, Rebmann C, Suyker A, Tenhunen J, Tu K, Verma S, Vesala T, Wilson K, Wofsy SC (2001). Gapfilling strategies for defensible annual sums of net ecosystem exchange. Agricultural and Forest Meteorology 107: 43-69. - doi: 10.1016/S0168-1923(00)00225-2

Fang Q, Sha LQ (2006). Soil respiration in a tropical seasonal rain forest and rubber plantation in Xishuangbanna, Yunnan, SW China. Chinese Journal of Plant Ecology 30: 97-103.

Germer J, Sauerborn J (2008). Estimation of the impact of oil palm plantation establishment on greenhouse gas balance. Environment, Development and Sustainability 10: 697-716. - doi: 10.1007/s10668-006-9080-1

Goulden ML, Munger JW, Fan SM, Daube BC, Wofsy SC (1996). Measurementsof carbon sequestration by long-term eddy covariance: methods and a critical evaluation of accuracy. Global Change Biology 2: 169-182. - doi: 10.1111/ j.1365-2486.1996.tb00070.x

Jiang JS, Wang RS (2002). Fuction of carbon sequestration and oxygen release of rubber plantations and its value estimation. Acta Ecologica Sinica 22: 1545-1551.

Kato T, Tan Y (2008). Spatial variability and major controlling factors of $\mathrm{CO}_{2}$ sink strength in Asian terrestrial ecosystems: evidence from eddy covariance data. Global Change Biology 14, 333-2348. - doi: 10.1111/j.1365-2486.2008.016 46.x

Kira T, Shidei T (1967). Primary production and turnover of organicmatter in different forest ecosystems of the western Pacific. Japanese Journal of Ecology 17: 70-87.

Knohl A, Schulze ED, Wirth C (2009). Biosphereatmosphere exchange of old-growth forests: processes and pattern. In: "Old-growth forests: Function, fate and value" (Wirth C, Gleixner G, Heimann M eds). Ecological Studies, Springer,
New York, Berlin, Heidelberg.

Lasslop G, Reichstein M, Papale D, Richardson AD, Arneth A, Barr A, Stoy P, Wohlfahrt G (2010). Seperation of net ecosystem exchange into assimilation and respiration using a light response curve approach: critical issues and global evaluation. Global Change Biology 16: 187-208. - doi: 10.1111/j.1365-2486.2009.02041.x

Lieth H, Whittaker RH (1975). Primary productivity of the biosphere. Ecological Studies 14, Springer-Verlag, Berlin, Germany.

Lu HZ, Sha LQ, Wang J, Hu WY, Wu BX (2009). Seasonal variation of soil respiration and its components in tropical rain forest and rubber plantation in Xishuangbanna, Yunnan. Chinese Journal of Applied Ecology 20: 2315-2322.

Malhi Y, Nobre AD, Grace J, Kruijt B, Pereira GPP, Culf A, Steve S (1998). Carbon dioxide transfer over a Central Amazonian rain forest. Journal of Geophysical Research: Atmospheres 103: 31593-31612. - doi: 10.1029/98JD02647 Miller SD, Goulden ML, Menton MC, da Rocha HR, de Freitas HC, Figueira AM, Dias de Sousa CA (2004). Biometric and micrometeorological measurements of tropical forest carbon balance. Ecological Applications 14: 114-126. - doi: 10.1890/02-6005

Moffat AM, Papale D, Reichstein M, Hollinger DY, Richardson AD, Barr AG, Beckstein C, Braswell B H, Churkina G, Desai AR, Falge E, Gove JH, Heimann M, Hui DF, Jarvis AJ, Kattge J, Noormets A, Stauch VJ (2007). Comprehensive comparison of gap-filling techniques for eddy covariance net carbon fluxes. Agricultural and Forest Meteorology 147: 209-232. - doi: 10.1016/j.agrformet.2007.08.011

Hashimotio T, Kojim K, Tange T, Sasaki S (2000). Changes in carbon storage in fallow forests in the tropical lowlands of Borneo. Forest Ecology and Management 3: 31-337. - doi: 10.1016/S0378-1127(99)00104-8

Houghton RA, Goodale C (2004). Effects of landuse change on the carbon balance of terrestrial ecosystems. Geophysical Monograph Series 153: 85-98. - doi: 10.1029/153GM08

Houghton RA (2005). Aboveground Forest Biomass and the Global Carbon Balance. Global Change Biology 11: 945-958. - doi: 10.1111/j. 1365-2486.2005.00955.x

Hutyra LR, Munger JW, Saleska SR, Gottlieb E, Daube BC, Dunn AL, Amaral DF, de Camargo PB, Wofsy SC (2007). Seasonal controls on the exchange of carbon and water in an Amazonian rain forest. Journal of Geophysical Research: Atmospheres 112: G03008. - doi: 10.1029/2006JG 000365.

Papale P, Moretti R, Barbato D (2006). The compositional dependence of the saturation surface of $\mathrm{H}_{2} \mathrm{O}+\mathrm{CO}_{2}$ fluids in silicate melts. Chemical Geology 229: 78-95. - doi: 10.1016/j.chemgeo. 2006.01.013

Reichstein M, Fagle E, Baldocchi DD, Papale D, Aubinet $\mathrm{M}$, Berbigier $\mathrm{P}$, Bernhofer C, Buchmann N, Gilmanov T, Loustau D, Matteucci G, Meyers T, Miglietta F, Ourcival JM, Pumpanen J, Rambal S, Rotenberg E, Sanz M, Tenhunen J, 
Seufert G, Vaccari G, Vesala T, Yakir D, Valentini R (2005). On the separation of net ecosystem exchange into assimilation and ecosystem respiration: review and improved algorithm. Global Change Biology 11: 1424-1439. - doi 10.1111/j.1365-2486.2009.02041.x

Saleska SR, Miller SC, Matross DM, Goulden ML,Wofsy SC, da Rocha HR, de Camargo PB, Crill P, Daube BC, de Freitas HC, Hutyra L, Keller M, Kirchhoff V, Menton M, Munger JW, Pyle EH, Pyle AH, Silva H (2003). Carbon in Amazon forests: unexpected seasonal fluxes and disturbance induced losses. Science 302: 1554 1557. - doi: 10.1126/science. 1091165

Takanashi S, Kosugi Y, Tani M, Matsuo N, Mitani T, Nik AR (2005). Characteristics of the gas exchange of a tropical rain forest in Peninsular Malaysia. Phyton 45: 61-66.

Tan ZH, Zhang YP, Yu GR, Sha LQ, Tang JW, Deng XB, Song QH (2010). Carbon balance of a primary tropical seasonal rain forest. Journal of Geophysical Research: Atmospheres 115: D00H26. - doi: 10.1029/2009JD012913

Tan ZH, Zhang YP, Schaefer D, Yu GR, Liang NS, Song QH (2011). An old-growth subtropical Asian evergreen forest as a large carbon sink. Atmospheric Environment 45: 1548-1554. - doi: 10.1016/j.atmosenv.2010.12.041
Tan ZH, Zhang YP, Song QH, Liu WJ, Deng XB, Tang, JW, Deng Y, Zhou WJ, Yang LY, Yu GR, Sun XM, Liang NS (2012). Rubber plantations act as water pumps in tropical China. Geophysical Research Letters 38: L24406. - doi: 10.1029/ 2011GL050006

Tanner CB, Thurtell GW (1969). Anemoclinometer measurements of Reynolds stress and heat transport in the atmospheric surface layer. ECOM66-G22-F, University of Wisconsin, Madison, WI, USA.

Tang JW, Pang JP, Chen MY, Guo XM, Zeng R (2009). Biomass and its estimation model of rubber plantations in Xishuangbanna, Southwest China. Chinese Journal of Ecology 28: 19421948.

Valentini R, Matteucci G, Dolman AJ, Schulze ED, Rebmann C, Moors E, Granier A, Gross P, Jensen NO, Pilegaard K (2000). Respiration as the main determinant of carbon balance in $\mathrm{Eu}-$ ropean forests. Nature 404: 861-865. - doi: 10.1038/35009084

Webb EK, Pearman GI, Leuning R (1980). Correction of flux measurement for density effects due to heat and water vapour transfer. Geophysical Journal of the Royal Astronomical Society 106: 85-100.

Wolf S, Eugster W, Potvin C, L Turner B, Buch- mann N (2011). Carbon sequestration potential of tropical pasture compared with afforestation in Panama. Global Change Biology 17: 27632780. - doi: 10.1111/j.1365-2486.2011.02460.x Zhang K (1966). An analysis on the characteristics and forming factors of climates in the southern part of Yunnan. Acta Meteorologica Sinica 33: 210-230.

\section{Supplementary Material}

Fig. S1 - The tower in the rubber plantation.

Fig. S2 - The relationship between net radiation $(\mathrm{Rn})$ and the sum of latent heat (LE) and sensible heat $(\mathrm{H})$.

Fig. S3 - The power spectrum of wind velocity components for air near forest floor in rubber plantation.

Fig. S4 - Light response of daytime flux and the temperature response of nighttime flux.

Fig. S5 - Cumulative frequency distribution of wind speed.

Link: Song_891@supp1001.pdf 